\title{
Temporal changes in soil bacterial and archaeal communities with different fertilizers in tea orchards ${ }^{* \#}$
}

\author{
Hua $\mathrm{WANG}^{1}$, Shao-hui YANG ${ }^{1}$, Jing-ping $\mathrm{YANG}^{\dagger+1}$, Ya-min $\mathrm{LV}^{1}$, Xing ZHAO ${ }^{1}$, Ji-liang $\mathrm{PANG}^{2}$ \\ ( ${ }^{1}$ Institute of Environmental Protection, College of Environmental and Resource Sciences, Zhejiang University, Hangzhou 310058, China) \\ $\left({ }^{2}\right.$ College of Life and Environmental Sciences, Hangzhou Normal University, Hangzhou 310036, China) \\ ${ }^{\dagger}$ E-mail: jpyang@zju.edu.cn
}

Received Apr. 22, 2014; Revision accepted Aug. 31, 2014; Crosschecked Oct. 15, 2014

\begin{abstract}
It is important to understand the effects of temporal changes in microbial communities in the acidic soils of tea orchards with different fertilizers. A field experiment involving organic fertilizer (OF), chemical fertilizer (CF), and unfertilized control (CK) treatments was arranged to analyze the temporal changes in the bacterial and archaeal communities at bimonthly intervals based on the 16S ribosomal RNA (rRNA) gene using terminal restriction fragment length polymorphism (T-RFLP) profiling. The abundances of total bacteria, total archaea, and selected functional genes (bacterial and archaeal amoA, bacterial narG, nirK, nirS, and nosZ) were determined by quantitative polymerase chain reaction (qPCR). The results indicate that the structures of bacterial and archaeal communities varied significantly with time and fertilization based on changes in the relative abundance of dominant T-RFs. The abundancy of the detected genes changed with time. The total bacteria, total archaea, and archaeal amo $A$ were less abundant in July. The bacterial $a m o A$ and denitrifying genes were less abundant in September, except the nirK gene. The OF treatment increased the abundance of the observed genes, while the CF treatment had little influence on them. The soil temperature significantly affected the bacterial and archaeal community structures. The soil moisture was significantly correlated with the abundance of denitrifying genes. Of the soil chemical properties, soil organic carbon was the most important factor and was significantly correlated with the abundance of the detected genes, except the nirK gene. Overall, this study demonstrated the effects of both temporal alteration and organic fertilizer on the structures of microbial communities and the abundance of genes involved in the nitrogen cycle.
\end{abstract}

Key words: Bacterial and archaeal communities, Fertilizer, Soil, Temporal changes, Tea orchard, Functional genes doi:10.1631/jzus.B1400114

Document code: A

CLC number: S154.3

\section{Introduction}

Soil microbial communities can affect the crop quality, the sustainability of agro-ecosystems (Stark et al., 2008), and the biogeochemical cycle of soil nutrients (Buckley and Schmidt, 2003). The soil ni-

\footnotetext{
Corresponding author

* Project supported by the Research Fund for the Doctoral Program of Higher Education of China (No. 20130101110127) and the Project of Zhejiang Key Scientific and Technological Innovation Team (No. 2010R50039), China

\# Electronic supplementary materials: The online version of this article (http://dx.doi.org/10.1631/jzus.B1400114) contains supplementary materials, which are available to authorized users

(C) Zhejiang University and Springer-Verlag Berlin Heidelberg 2014
}

trogen $(\mathrm{N})$ cycle contains two important processes: nitrification and denitrification. The oxidation of ammonia, the first and rate-limiting step of nitrification, is catalyzed by ammonia monooxygenase. This enzyme is encoded by the amo $A$ gene from ammoniaoxidizing bacteria (AOB) and ammonia-oxidizing archaea (AOA), which may occupy different ecological niches (Prosser and Nicol, 2012). Denitrification, a four-step reducing process that is catalyzed by key enzymes encoded by the $\operatorname{nar} G$, nirK, nirS, and nosZ genes (Zumft, 1997), plays an important role in the reduction of nitrate to gaseous nitrogen. Studies of the nitrifiers and denitrifiers are commonly focused on functional genes, such as amoA, $\operatorname{nar} G, \operatorname{nirK}$, and $\operatorname{nir} S$ (Szukics et al., 2010; Di et al., 2014). 
The application of chemical fertilizer (CF) can increase the crop yield but changes the soil properties and results in $\mathrm{N}$ loss from agricultural systems (Galloway et al., 2003). CF increases the microbial biomass and changes the bacterial community structure (Peacock et al., 2001); however, it does not significantly increase the bacterial abundance (Chen et al., 2012) or decrease the bacterial and archaeal abundances in long-term experiments (Hallin et al., 2009; Chan et al., 2013). Organic fertilizer (OF), an alternative to $\mathrm{CF}$, mitigates $\mathrm{N}$ pollution from agriculture ecosystems. The organic matter amendment not only increases the microbial biomass (Peacock et al., 2001) and total bacterial and archaeal abundance (Hallin et al., 2009; Chan et al., 2013), but also changes the structure of bacterial community through the increased soil organic carbon (SOC) content.

Shen et al. (2008) and Ai et al. (2013) found that chemical $\mathrm{N}$ fertilizer changed the AOB community structure and increased the soil potential nitrification activity (PNA) and $\mathrm{AOB}$ abundance, but $\mathrm{He}$ et al. (2007) reported that soil PNA and AOB abundances decreased with the application of a chemical $\mathrm{N}$ fertilizer. The effect of chemical $\mathrm{N}$ fertilizer on the abundance of AOA varies due to the soil $\mathrm{pH}$ (He et al., 2007; Shen et al., 2008; Ai et al., 2013). Manure amendment significantly increased the AOB abundance in a paddy field with long-term fertilization (Wang et al., 2014) but not in other systems (Wessén et al., 2010; Ai et al., 2013). For AOA, manure increased the AOA abundance and changed the community structure (Wessén et al., 2010; Ai et al., 2013). For denitrifiers, the influence of chemical $\mathrm{N}$ fertilizer and OF has been well studied but appears to have incongruent effects on denitrifier community composition (Wolsing and Priemé, 2004; Enwall et al., 2005; Clark et al., 2012). In a long-term experiment, ammonium fertilizer significantly decreased the abundance of denitrifiers (Hallin et al., 2009). Manure amendment increased the abundance of denitrifying genes both at the DNA and RNA levels (Hallin et al., 2009; Clark et al., 2012; Saunders et al., 2012).

It is important to study the temporal changes in soil microbial communities because temporal analyses may help to comprehensively explain the soil function and provide insight into the environmental niches that are inhabited by diverse soil microbes (Lauber et al., 2013). The abundances and community structures of bacteria and archaea (He et al., 2007; Rasche et al., 2011), including ammonia-oxidizing ones (He et al., 2007; Szukics et al., 2010), vary temporally due to changes in the soil properties. For denitrifiers, previous studies have demonstrated that the temporal effect on the abundance of denitrifying genes varies among different genes (Wolsing and Priemé, 2004; Dandie et al., 2008). A temporal shift in the denitrifier community composition has also been reported (Wolsing and Priemé, 2004; Dandie et al., 2008; Szukics et al., 2010).

Tea (Camellia sinensis) is an important cash crop in southern China. The soil $\mathrm{pH}$ in tea orchards is relatively low because of the tea plantations and high-level applications of chemical $\mathrm{N}$ fertilizers, especially urea (Yao et al., 2011). However, the study of the temporal changes in the soil microbial communities that are related to OF treatment is relatively rare in tea orchards. Therefore, this study focused on the temporal changes of the bacterial and archaeal communities and functional groups as related to nitrification and denitrification under different types of fertilizer treatments. The major hypotheses were (1) that fertilizer amendments would influence the structures of bacterial and archaeal communities and the abundances of the functional groups that are involved in nitrification and denitrification in tea orchards, and (2) that the temporal variability in microbial community structures and the abundance of detected genes may be related to soil climate changes, such as soil temperature and moisture variation. In this study, the abundances and community structures of total bacteria and total archaea, as well as the abundances of denitrifying (narG, nirS, nirK, and $n o s Z$ ) and nitrifying (AOA and $\mathrm{AOB}$ ) functional groups were investigated.

\section{Materials and methods}

\subsection{Field site, experimental design, and soil sampling}

The present study was conducted in the Jingshan tea production field $\left(119^{\circ} 53^{\prime} \mathrm{E}, 30^{\circ} 23^{\prime} \mathrm{N}\right)$, Hangzhou, China. This area has a subtropical monsoon climate with an annual average air temperature of $17^{\circ} \mathrm{C}$ and annual average rainfall of $1400 \mathrm{~mm}$. The soil of the tea field is red clay, and the topsoil $(0-10 \mathrm{~cm})$ has a 
$\mathrm{pH}\left(\mathrm{H}_{2} \mathrm{O}\right)$ value of 3.72 , SOC of $35.80 \mathrm{~g} / \mathrm{kg}$, and total nitrogen $(\mathrm{TN})$ level of $3.16 \mathrm{~g} / \mathrm{kg}$. The tea plants $(C$. sinensis $\mathrm{L}$.) in the field were approximately 40 years old. The farmer applied CF, including urea and calcium superphosphate, three times (in March, June, and October) per year before the study was conducted to improve the tea yield.

The field experiment began in March 2012 with nine experimental plots that were $5 \mathrm{~m}$ wide and $20 \mathrm{~m}$ long. The plots were separated by a concrete wall that was $35 \mathrm{~cm}$ high aboveground and $30 \mathrm{~cm}$ deep underground to prevent water flow between the plots. The applied fertilizer treatments in this study included unfertilized control (CK), OF, and CF. The properties and application details of the fertilizers are shown in Table 1. To be consistent with the tea cultivation by the native farmers, the fertilizer was applied in three split applications in 2012. The experimental design was a completely randomized design, and each fertilizer treatment had three replicates. The fertilizer for each plot was applied equally to the rows between the tea plants.

Soil sampling was conducted every two months from May 17, 2012 to March 17, 2013. The soil sample of each plot was composed of 12 soil cores that were collected along zigzag paths (zigzag sampling) from the surface layer $(0-10 \mathrm{~cm})$. All of the soil cores were sampled from fertilized rows. A total of 12 soil cores from each plot were delivered on ice to the laboratory and were then pooled and sieved through 2- or 5-mm mesh (wet soils). Visible pieces of plant material and soil-dwelling animals were removed. To measure the soil ammonium and nitrate levels and perform a molecular analysis, the soil subsamples were stored at $-20^{\circ} \mathrm{C}$. The soils were air-dried before the measurements of SOC, TN, and $\mathrm{pH}$.

\subsection{Soil property analysis}

The soil moisture content was determined by oven-drying $10 \mathrm{~g}$ of soil at $105{ }^{\circ} \mathrm{C}$ for $24 \mathrm{~h}$, and the results are presented based on the soil weight loss. The soil temperature was measured using a digital thermometer at a depth of $10 \mathrm{~cm}$. The soil $\mathrm{pH}$ was determined by a digital $\mathrm{pH}$ meter after extracting with water ( $1 \mathrm{~g}$ soil extracted with $2.5 \mathrm{ml}$ water). The SOC and TN were analyzed by oxidation with dichromate (Nelson and Sommers, 1982) and Kjeldahl determination (VELP Scientifica, Italy), respectively. The ammonium and nitrate contents were determined using the indo-phenol-blue colorimetric method (Sun, 2007) and dual-wavelength ultraviolet spectrophotometry (Norman et al., 1985), respectively, after extracting with $2 \mathrm{~mol} / \mathrm{L} \mathrm{KCl}$ solution ( $1 \mathrm{~g}$ soil extracted with $5 \mathrm{ml} \mathrm{KCl}$ solution).

\subsection{DNA extraction and quantitative polymerase chain reaction (qPCR) analysis}

DNA was extracted from $0.5 \mathrm{~g}$ of soil using the FastDNA Spin Kit for Soil (MP Biomedicals, USA).

The abundances of the total bacteria, total archaea, bacterial and archaeal amoA genes, and the bacterial $\operatorname{nar} G$, nir $S$, nirK, and nosZ genes were determined by qPCR with an ABI 7500 instrument (Applied Biosystems, USA). The PCR procedures and primers are shown in Table $S 1$. Each reaction was performed in a volume of $25 \mu \mathrm{l}$ containing $0.4 \mu \mathrm{l}$ of each primer $(10 \mu \mathrm{mol} / \mathrm{L}), 0.5 \mu \mathrm{l}$ of ROXII (TaKaRa, Japan), $12.5 \mu 1$ of $2 \times$ SYGB buffer (TaKaRa), $0.625 \mu \mathrm{l}$ of DMSO, $0.875 \mu \mathrm{l}$ of $3 \%$ bovine serum albumin (BSA), and 10 ng of template. For the standard curves, the amplicons of the detected genes were purified using the Cycle-Pure Kit (Omega Bio-Tek, USA), ligated into the vector pMD18-T (TaKaRa) and then transformed into Escherichia coli TOP10 competent cells. The plasmids were extracted using the Plasmid Mini Kit (Omega Bio-Tek) and checked using the basic local alignment search tool (BLAST). A NanoDrop 2000 (Thermo, USA) was used to measure the concentrations of the plasmids. The plasmids were serially diluted to generate the standard curves.

Table 1 Properties and application details of the fertilizers

\begin{tabular}{|c|c|c|c|c|c|c|}
\hline \multirow{2}{*}{ Treatment } & \multirow{2}{*}{ Fertilizer } & \multirow{2}{*}{$\begin{array}{c}\mathrm{TN} \\
(\mathrm{g} / \mathrm{kg})\end{array}$} & \multirow{2}{*}{$\begin{array}{c}\text { AP } \\
(\mathrm{g} / \mathrm{kg})\end{array}$} & \multicolumn{3}{|c|}{ Application of fertilizer } \\
\hline & & & & Mar. 21 & June 14 & Oct. 26 \\
\hline $\mathrm{CF}$ & Urea and calcium superphosphate & 464.0 & 126.0 & $\begin{array}{c}120 \mathrm{~kg} \mathrm{~N} / \mathrm{ha}, \\
40 \mathrm{~kg} \mathrm{P} / \mathrm{ha}\end{array}$ & $\begin{array}{l}90 \mathrm{~kg} \mathrm{~N} / \mathrm{ha}, \\
30 \mathrm{~kg} \mathrm{P} / \mathrm{ha}\end{array}$ & $\begin{array}{l}90 \mathrm{~kg} \mathrm{~N} / \mathrm{ha}, \\
30 \mathrm{~kg} \mathrm{P} / \mathrm{ha}\end{array}$ \\
\hline OF & $\begin{array}{l}\text { Commercially made from manure } \\
\text { of pig, chicken, etc. }\end{array}$ & 31.8 & 11.0 & $\begin{array}{l}120 \mathrm{~kg} \mathrm{~N} / \mathrm{ha} \\
40 \mathrm{~kg} \mathrm{P} / \mathrm{ha}\end{array}$ & $\begin{array}{l}90 \mathrm{~kg} \mathrm{~N} / \mathrm{ha}, \\
30 \mathrm{~kg} \mathrm{P} / \mathrm{ha}\end{array}$ & $\begin{array}{l}90 \mathrm{~kg} \mathrm{~N} / \mathrm{ha}, \\
30 \mathrm{~kg} \mathrm{P} / \mathrm{ha}\end{array}$ \\
\hline
\end{tabular}

CF: chemical fertilizer; OF: organic fertilizer; TN: total nitrogen; AP: available phosphorus 


\subsection{Microbial community analysis by terminal restriction fragment length polymorphism (T-RFLP)}

For T-RFLP, the bacterial and archaeal $16 \mathrm{~S}$ ribosomal RNA (rRNA) genes were amplified using FAM-labeled forward primers. The PCR was performed in a 1000 Thermal Cycler (Bio-Rad, USA). The primer sets and amplification details of the PCR for T-RFLP are shown in Table S1. The $50 \mu 1$ PCR cocktail contained $10 \mathrm{ng}$ of DNA, $0.15 \mu \mathrm{mol} / \mathrm{L}$ of each primer, $0.2 \mathrm{mmol} / \mathrm{L}$ dNTPs, $0.5 \mathrm{mg} / \mathrm{ml}$ BSA, $4 \mathrm{mmol} / \mathrm{L} \mathrm{Mg}^{2+}, 2 \mathrm{U}$ of HS Taq (TaKaRa), and a $1 \times$ reaction buffer that was provided with the enzyme. Duplicate amplifications from each sample were mixed and purified using a gel extraction kit (Omega Bio-Tek). The bacterial and archaeal amplicons were digested with $H h a$ I and $A l u$ I (NEB, USA), respectively, at $37{ }^{\circ} \mathrm{C}$ for $3 \mathrm{~h}$. A $2-\mu 1$ aliquot of each digest was mixed with $12 \mu 1$ of formamide and $0.3 \mu l$ of the internal size standard (ROX-500, Applied Biosystems) and detected on an ABI 3730xl genetic analyzer (Applied Biosystems). The fragments were analyzed using the GeneMapper software (Version 4.0, Applied Biosystems). The height of each peak was expressed as the percentage of all of the peak heights in the profile. The peak was included for further analysis if its length was between 50 and $500 \mathrm{bp}$ and its percentage was $>1 \%$.

\subsection{Statistical analysis}

For the soil properties and qPCR data that were not normally distributed, the data were logtransformed. A repeated-measure analysis of variance (ANOVA) was performed to analyze the effect of fertilizer and sampling time on the soil properties and qPCR data. We compared the significant differences among the fertilizers at each sampling time using Tukey's test. A correlation analysis was used to examine the relationship between the soil properties and the abundance of phylogenetic and functional markers. Statistical analyses were performed with SPSS V16.0.

The T-RFLP data were square-root-transformed prior to analysis. A two-way interactive permutational multivariate ANOVA (PERMANOVA) (Anderson, 2001) was conducted to assess the effect of fertilizer and sampling time on the bacterial and archaeal communities. The pairwise comparisons in the
PERMANOVA were used to determine whether the bacterial and archaeal communities were altered by fertilizer at each sampling time. The PERMANOVA generated a Monte Carlo asymptotic $P$-value ( $\left.P_{-} \mathrm{MC}\right)$ when the pairwise comparisons were conducted. The microbial communities significantly differed among the fertilizer treatments if $P_{-} \mathrm{MC}<0.05$. Nonmetric multidimensional scaling (nmMDS) based on the Bray-Curtis similarity coefficients was used to analyze the relatedness of individual community profiles with all treatments conducted with Primer V5.0 software (PRIMER-E, UK). A redundancy analysis (RDA) with the Monte Carlo permutation test with 999 permutations was performed with Canoco (Version 4.5 for Windows, Biometrics Plant Research International, the Netherlands) to test the influence of the soil properties on the microbial community.

\section{Results}

\subsection{Soil properties}

The soil properties varied significantly with the fertilizers and sampling time $(P<0.01)$. However, the interaction between the fertilizers and sampling time only significantly influenced the soil ammonium and nitrate levels $(P<0.01)$. The soil TN, ammonium, and nitrate levels were higher under the CF treatment, but the soil $\mathrm{pH}$ was significantly lower under the $\mathrm{CF}$ treatment than under the OF or CK treatment, except on November 18th (Table S2). The OF treatment had a higher SOC content.

\subsection{Abundances of bacteria and archaea}

The abundances of total bacteria and archaea under the $\mathrm{OF}, \mathrm{CF}$, and $\mathrm{CK}$ treatments changed similarly with respect to the sampling time and was lowest on July 19th (Fig. 1). The OF treatment had the highest copy numbers of total bacterial and archaeal 16S rRNA genes, ranging from $1.7 \times 10^{9}$ to $4.9 \times 10^{9}$ and $1.3 \times 10^{7}$ to $1.1 \times 10^{8}$ copies per gram of dry soil, respectively (Fig. 1). A greater bacterial abundance was detected under the $\mathrm{CF}$ treatment than under the $\mathrm{CK}$ treatment with an exception on July 19th, but a significant difference was only shown on January 15 th. No significant difference was detected for the archaeal abundance between the $\mathrm{CF}$ and $\mathrm{CK}$ treatments. 


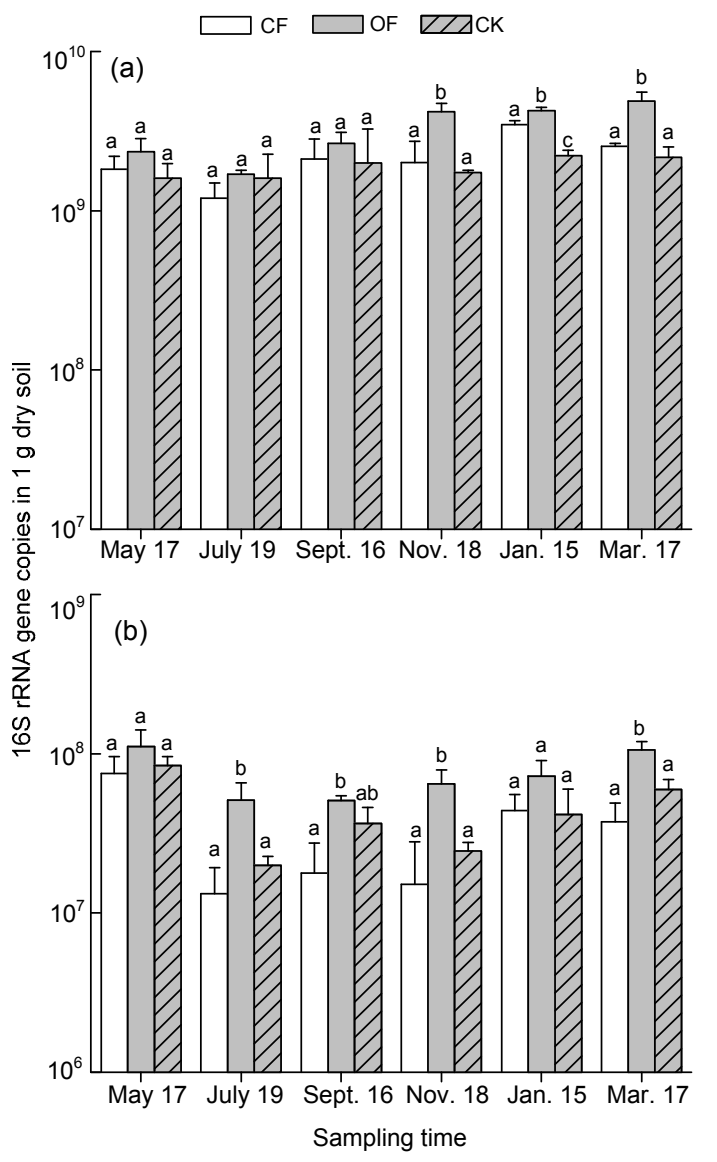

Fig. 1 Quantitative PCR data of the total bacteria (a) and total archaea (b) in organic fertilizer (OF), chemical fertilizer (CF), and unfertilized control (CK) treatments over one year

Data are expressed as mean $\pm \mathrm{SD}, n=3$. The letters above the bars indicate significant differences $(P<0.05)$ among the fertilizers for each sampling time. The $Y$ axis is a logarithmic coordinate axis

\subsection{Abundances of the bacterial and archaeal amo $A$ genes}

Both of the bacterial and archaeal amoA gene copy numbers changed significantly with the sampling time $(P<0.01)$. The archaeal amoA gene copy number changed from $3.7 \times 10^{5}$ to $2.3 \times 10^{7}$ copies per gram of dry soil and was lowest on July 19th (Fig. 2a). The population size of AOB was lower than that of AOA (Fig. 2b), the lowest AOB abundance was on September 16th, when no significant differences were detected among the three treatments. The OF treatment resulted in the greatest abundance of both the bacterial and archaeal amo $A$ genes.

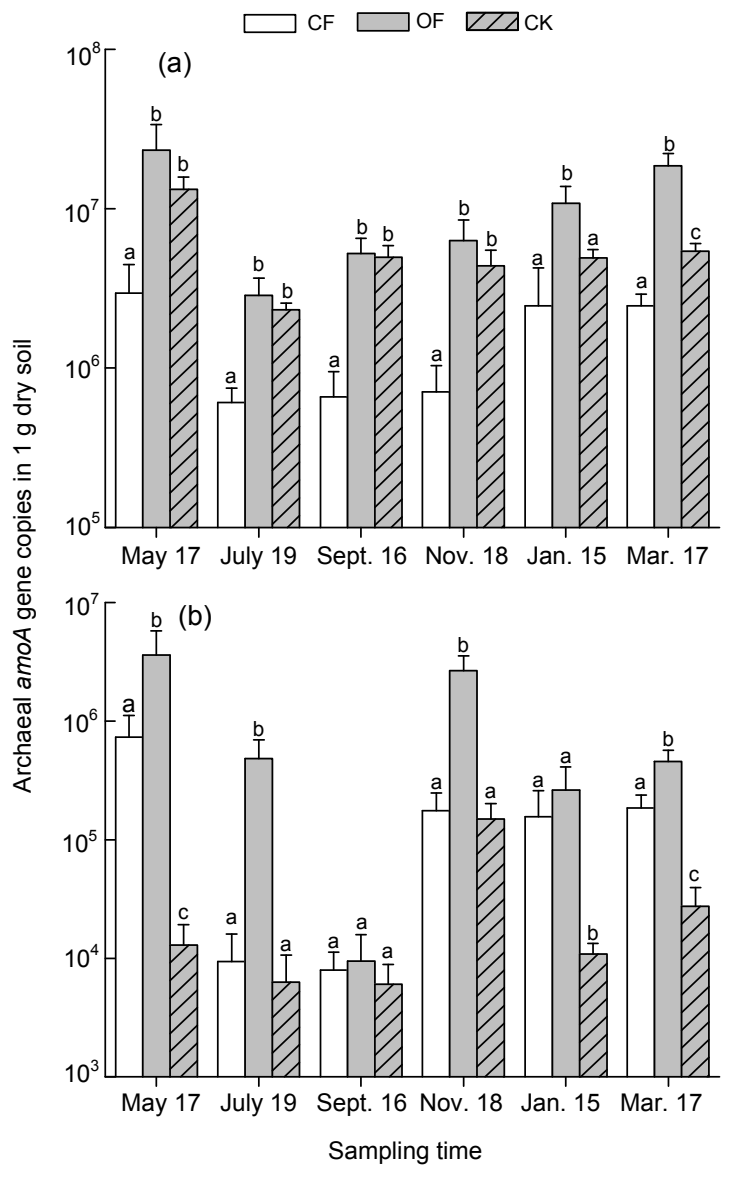

Fig. 2 Quantitative PCR data of the archaeal (a) and bacterial (b) amoA genes in organic fertilizer (OF), chemical fertilizer (CF), and unfertilized control (CK) treatments over one year

Data are expressed as mean $\pm \mathrm{SD}, n=3$. The letters above the bars indicate significant differences $(P<0.05)$ among the fertilizers for each sampling time. The $Y$ axis is a logarithmic coordinate axis

\subsection{Abundance of denitrifiers}

All of the detected denitrifying genes were more abundant under the OF treatment, but the effect was not always significant (Fig. 3). No significant difference was found when comparing the CF treatment with the CK treatment, with the exception of January 15th when the $\operatorname{nar} G$ gene was more abundant under the $\mathrm{CF}$ treatment. The lowest denitrifying gene abundance was determined on September 16th except for that of nirK under the CF and CK treatments. The analysis of variance detected a significant variation of the abundance of denitrifying genes with the sampling time $(P<0.01)$. 

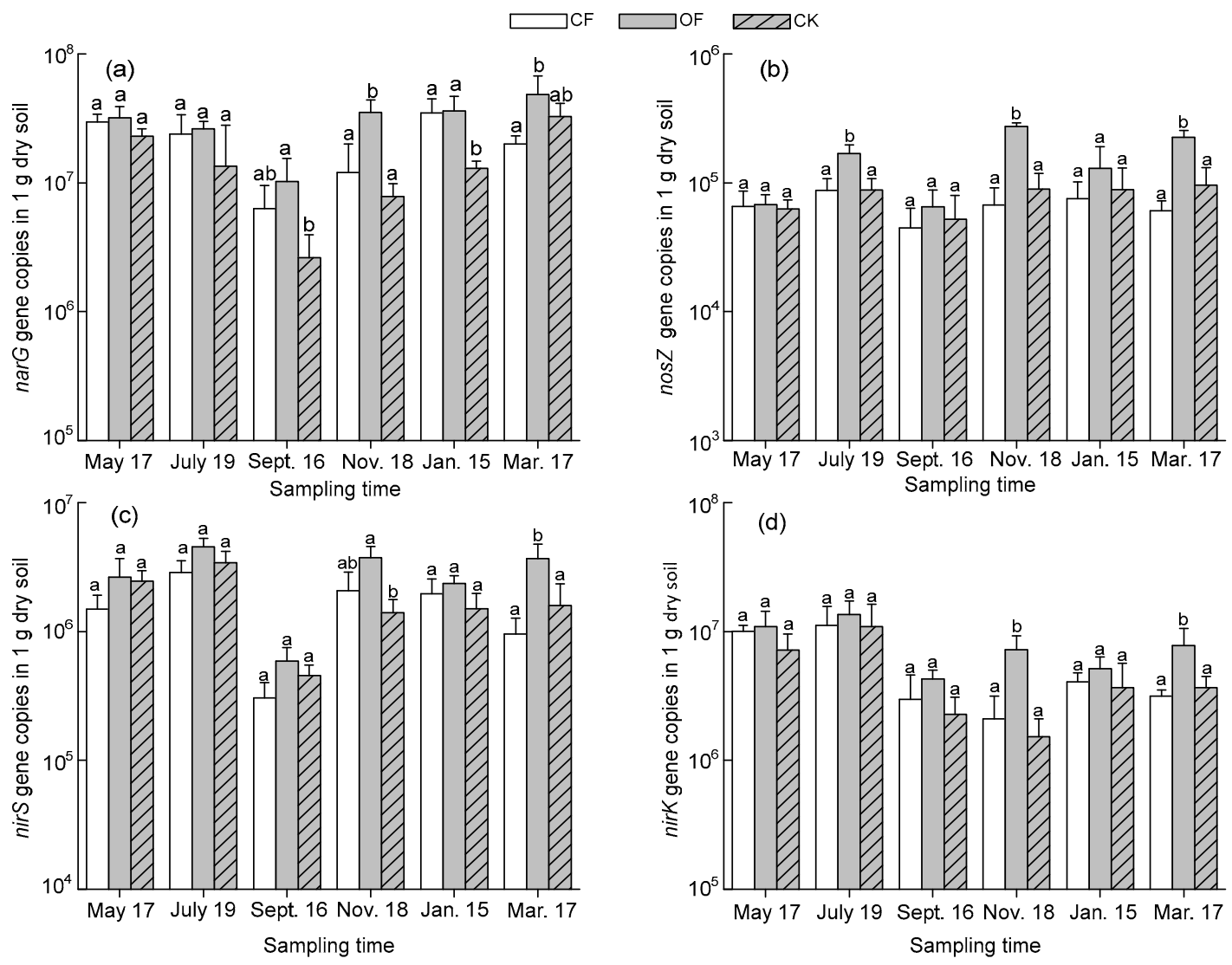

Fig. 3 Quantitative PCR data of the bacterial $\operatorname{nar} G(\mathrm{a}), \operatorname{nos} Z(\mathrm{~b}), \operatorname{nir} S$ (c), and $\operatorname{nirK}(\mathrm{d})$ genes in organic fertilizer (OF), chemical fertilizer (CF), and unfertilized control (CK) treatments over one year

Data are expressed as mean $\pm \mathrm{SD}, n=3$. The letters above the bars indicate significant differences $(P<0.05)$ among the fertilizers for each sampling time. The $Y$ axis is a logarithmic coordinate axis

\subsection{Bacterial and archaeal communities}

Bacterial community composition profiles showed 93 T-RFs across all of the profiles, of which three dominant fragments $(58,88$, and $372 \mathrm{bp})$ and a further six fragments $(63,74,211,279,294$, and $298 \mathrm{bp}$ ) comprised $>10 \%$ and $5 \%$ of the total abundance, respectively. The PERMANOVA analysis indicated a significant effect of the fertilizer and sampling time $(P<0.01)$, which was further supported by nmMDS analysis (Fig. S1a). However, no significant differences were detected between the $\mathrm{CF}$ and OF treatments in July, January, or March (Table 2). The relative abundance of T-RF-58 varied significantly with the fertilizer except on July 19th and September 16th (Fig. 4a). The relative abundance of T-RF-88 changed significantly among the three treatments from July 19th to March 17th. While the relative abundance of T-RF-372 was significantly higher under the CK treatment on July 19th, this fragment was not detected from September to March.

Table 2 Output of the PERMANOVA analysis demonstrating the fertilizer effect on the structures of soil bacterial and archaeal communities throughout the experimental period (May 2012 to March 2013)

\begin{tabular}{|c|c|c|c|c|c|c|}
\hline \multirow{3}{*}{$\begin{array}{c}\text { Sampling } \\
\text { time }\end{array}$} & \multicolumn{6}{|c|}{$P \_$MC value } \\
\hline & \multicolumn{3}{|c|}{ Bacterial community } & \multicolumn{3}{|c|}{ Archaeal community } \\
\hline & $\begin{array}{c}\text { CF vs. } \\
\text { OF }\end{array}$ & $\begin{array}{c}\text { CF vs. } \\
\text { CK }\end{array}$ & $\begin{array}{c}\text { OF vs. } \\
\text { CK }\end{array}$ & $\begin{array}{c}\text { CF vs. } \\
\text { OF }\end{array}$ & $\begin{array}{c}\text { CF vs. } \\
\text { CK }\end{array}$ & $\begin{array}{c}\text { OF vs. } \\
\text { CK }\end{array}$ \\
\hline May 17 & 0.024 & 0.003 & 0.030 & 0.004 & 0.004 & 0.014 \\
\hline July 19 & 0.071 & 0.029 & 0.006 & 0.055 & 0.015 & 0.036 \\
\hline Sept. 16 & 0.027 & 0.013 & 0.009 & 0.005 & 0.007 & 0.011 \\
\hline Nov. 18 & 0.048 & 0.012 & 0.005 & 0.003 & 0.004 & 0.012 \\
\hline Jan. 15 & 0.079 & 0.002 & 0.010 & 0.010 & 0.003 & 0.032 \\
\hline Mar. 17 & 0.077 & 0.033 & 0.050 & 0.002 & 0.004 & 0.037 \\
\hline
\end{tabular}

$P$ _MC: Monte Carlo asymptotic $P$-value 
The archaeal community analysis revealed 88 peaks across all of the profiles, with four major peaks $(141,404,405$, and $435 \mathrm{bp})$ and six peaks $(70$, $116,347,350,407$, and $500 \mathrm{bp}$ ) forming $>20 \%$ and $>5 \%$ of the total abundance, respectively. The nmMDS plot indicated differences among the treatments throughout the entire sampling time with a stress value of 0.18 (Fig. S1b), which are supported by the PERMANOVA analysis $(P<0.01)$. These dominant fragments varied significantly with the treatments. T-RF-404 was significantly more abundant under the $\mathrm{CF}$ treatment, while no significant difference was detected between the OF and CK treatments except on November 18th (Fig. 4b). The OF treatment but not the CF treatment significantly increased the relative abundance of T-RF-141. The relative abundance of T-RF-435 significantly decreased under the CF treatment except on January 15th, while the T-RF-405 fragment was more abundant under the CF treatment except on May 17th.

\subsection{Relationships between soil properties and microbial abundance and microbial community structure}

The SOC was significantly positively correlated with the abundance of all of the detected genes except for the archaeal amoA and nirK genes (Table 3). The abundance of AOA correlated negatively with nitrate but positively with the $\mathrm{pH}$ and the ratio of SOC to TN (C:N). The abundance of the nirK gene was only positively correlated with nitrate. The abundance of the nirS gene was negatively correlated with $\mathrm{TN}$ but positively correlated with the SOC and C:N. The $\mathrm{pH}$ was positively correlated with the abundances of total

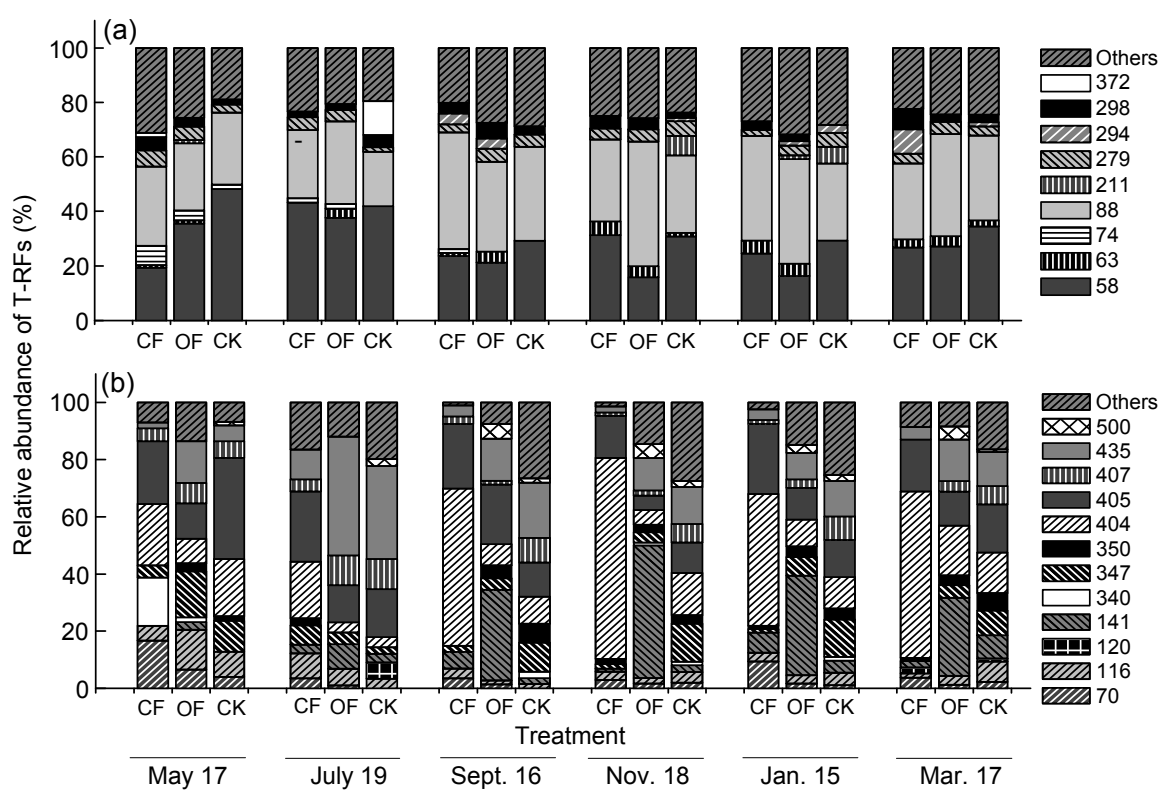

Fig. 4 Contributions of the major terminal restriction fragments (T-RFs) to the total bacterial (a) and archaeal (b) gene fragment diversities in organic fertilizer (OF), chemical fertilizer (CF), and unfertilized control (CK) treatments as determined over one year The T-RFs that never contributed more than $5 \%$ were summarized as "others"

Table 3 Pearson's linear correlation coefficients between the soil properties and the abundances of phylogenetic and functional markers

\begin{tabular}{|c|c|c|c|c|c|c|c|c|}
\hline \multirow{2}{*}{ Prokaryotic group } & \multicolumn{8}{|c|}{ Pearson's linear correlation coefficient } \\
\hline & Ammonium & Nitrate & $\mathrm{pH}$ & SOC & $\mathrm{TN}$ & $\mathrm{C}: \mathrm{N}$ & Temperature & Moisture \\
\hline Total bacteria & -0.007 & $-0.296^{*}$ & $0.355^{* *}$ & $0.434^{* *}$ & 0.114 & $0.283^{*}$ & $-0.554^{* *}$ & -0.024 \\
\hline Total archaea & 0.000 & -0.237 & 0.167 & $0.288^{*}$ & -0.017 & 0.252 & 0.023 & 0.162 \\
\hline Archaeal amoA gene & -0.210 & $-0.306^{*}$ & $0.446^{* *}$ & 0.235 & -0.171 & $0.333^{*}$ & 0.027 & 0.005 \\
\hline Bacterial amo $A$ gene & 0.067 & 0.080 & 0.001 & $0.275^{*}$ & -0.009 & 0.258 & 0.074 & 0.076 \\
\hline Bacterial nar $G$ gene & 0.153 & 0.017 & -0.018 & $0.302^{*}$ & 0.092 & 0.181 & -0.125 & $0.318^{* *}$ \\
\hline Bacterial nirK gene & -0.022 & $0.277^{*}$ & -0.197 & 0.160 & -0.139 & 0.263 & $0.645^{* *}$ & $0.286^{* *}$ \\
\hline Bacterial nirS gene & -0.098 & 0.002 & 0.110 & $0.295^{*}$ & $-0.270^{*}$ & $0.516^{* *}$ & 0.241 & $0.292^{* *}$ \\
\hline Bacterial nos $Z$ gene & -0.174 & -0.190 & $0.415^{* *}$ & $0.430^{* *}$ & -0.181 & $0.549^{* *}$ & -0.198 & 0.113 \\
\hline
\end{tabular}

\footnotetext{
${ }^{* *}$ Significant at the levels of 0.05 and 0.01 (two-tailed), respectively. C:N: ratio of soil organic carbon (SOC) to total nitrogen (TN)
} 
bacteria and the nos $Z$ gene. No significant correlation was found between the soil ammonium content and the abundance of any of the detected genes. The soil temperature was negatively correlated with the abundance of total bacteria and positively correlated with the abundance of the nirK gene. The soil moisture was positively correlated with the abundances of narG, $\operatorname{nirK}$, and nirS.

The relationship between the soil properties and the microbial communities under all of the treatments was analyzed using RDA (Fig. 5). The length of the arrow in the figure represents the effect of the soil properties on the microbial community distribution, which increased along the arrow's direction. The bacterial communities were mainly influenced $(P<0.05)$ by soil temperature, TN, C:N, ammonium, and moisture. Soil ammonium, temperature, $\mathrm{SOC}, \mathrm{pH}$, and $\mathrm{C}: \mathrm{N}$ significantly $(P<0.05)$ affected the archaeal communities. The cumulative variances of the species-environment relationship as explained by the first two axes were $69.60 \%$ and $76.70 \%$ for the bacterial and archaeal communities, respectively. The first axis explains the largest variation of the bacterial communities $(P<0.01)$ and archaeal communities $(P<0.01)$. For the bacterial communities, the first axis accounted for $13.40 \%$ of the variation in the species data and was strongly correlated with the soil temperature. The archaeal species data were changed mainly by the first axis, which attributed to $22.60 \%$ of the variation and was strongly correlated with the soil ammonium content, $\mathrm{pH}$, and $\mathrm{C}: \mathrm{N}$.

\section{Discussion}

\subsection{Temporal changes in the soil bacterial and archaeal communities under different fertilizer treatments}

We detected a significant effect of soil temperature on the community structures of the total bacteria and archaea, similar to other researchers (Rasche et al., 2011; Lauber et al., 2013). Temperature is an important factor in microbial community composition (Hayden et al., 2012). The Gram-positive $\left(\mathrm{G}^{+}\right)$bacterial abundance responds negatively to the winter months with lower soil temperatures (Bell et al., 2009). Elevated temperatures increase the abundance of $\mathrm{G}^{+}$bacteria, including Firmicutes and Actinobacteria, but decrease the abundance of Gram-nagative
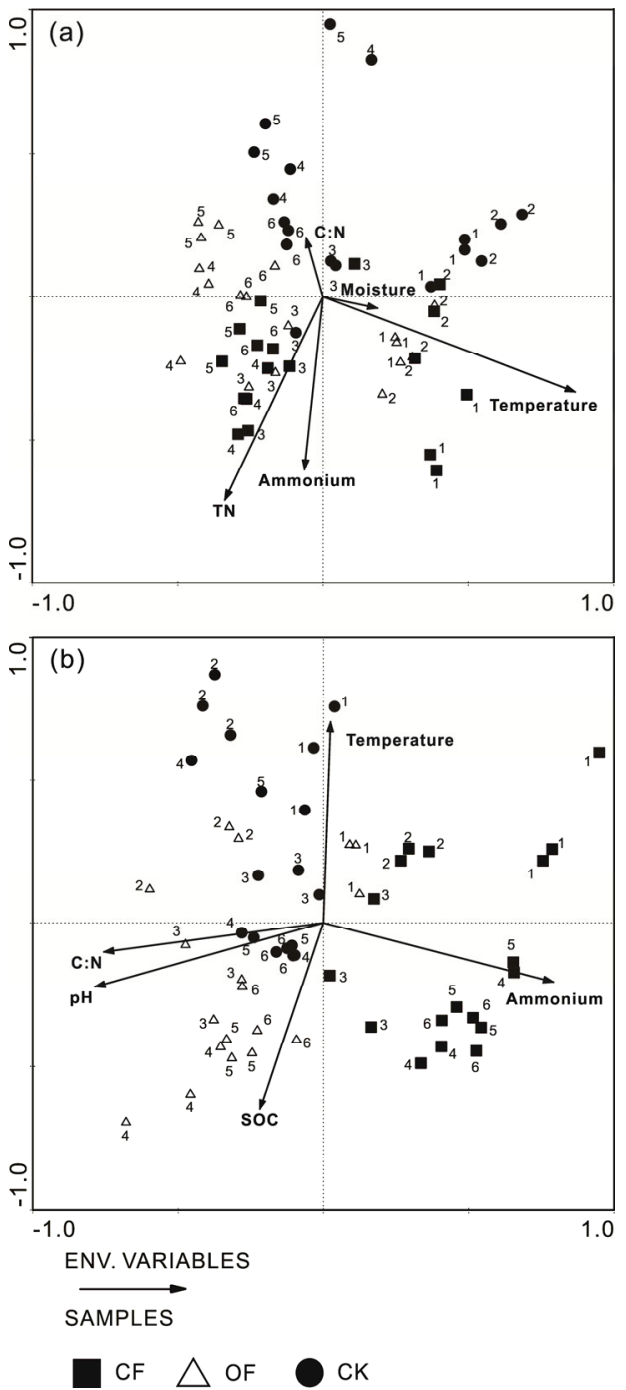

Fig. 5 Plots of a redundancy analysis of microbial communities based on the T-RFLP datasets that were obtained from the total bacteria (a) and total archaea (b) in the organic fertilizer (OF), chemical fertilizer (CF), and unfertilized control (CK) treatments

The numbers in the plots represent the sampling time: 1. May 17; 2. July 19 ; 3. Sept. 16; 4. Nov. 18; 5. Jan. 15; 6. Mar. 17. C:N is the ratio of soil organic carbon to total nitrogen. Only the statistically significant soil properties are shown

$\left(\mathrm{G}^{-}\right)$bacteria (Gray et al., 2011; Hayden et al., 2012). For archaeal community composition, Bomberg et al. (2011) found that the crenarchaeotal denaturing gradient gel electrophoresis (DGGE) band numbers decreased with increasing temperatures, while the number of euryarchaeotal DGGE bands increased. Interestingly, no significant differences were detected in the bacterial community structure between the $\mathrm{CF}$ 
and $\mathrm{OF}$ treatments three months after the last fertilization, indicating that the dynamics of the soil bacterial community structure was unrelated to the applied materials after a certain duration of fertilization. Such a time-related variation in the bacterial community was also found by Calbrix et al. (2007) and may be attributed to a seasonal effect. The bacterial and archaeal abundances changed significantly with the sampling time and were lower in the summer than in the winter (Rasche et al., 2011; Jung et al., 2012). In agreement with $\mathrm{He}$ et al. (2007), the abundance of total bacteria did not change significantly among the three treatments in the summer. Very low soil microbial counts were detected when the soil was sampled following a heavy rainfall (Pandey and Palni, 1996). There was a heavy rainfall (as great as $57 \mathrm{~mm}$ ) at the experimental site on July 17, which might be the reason for the lowest abundance of total bacteria and archaea being detected on July 19.

Fertilizer amendments increase the soil nutrient levels, including the soil SOC, TN, and ammonium contents, and thus influence the microbial community structure (Nicol et al., 2003; Böhme et al., 2005). However, long-term fertilization did not significantly change the bacterial community composition ( $\mathrm{He}$ et al., 2008; Ogilvie et al., 2008). Of the tested soil chemical properties, the $\mathrm{C}: \mathrm{N}$ and ammonium content significantly influenced the bacterial and archaeal community structures. OF directly increased the SOC and $\mathrm{pH}$, changed the soil $\mathrm{C}: \mathrm{N}$ and supported the growth of specific microorganisms (Marschner et al., 2003; Gattinger et al., 2007). For example, Marschner et al. (2003) found that $\mathrm{OF}$ increased the ratio of $\mathrm{G}^{+}$to $\mathrm{G}^{-}$bacteria compared to the ratio under inorganic fertilizer. The mechanisms by which inorganic $\mathrm{N}$ fertilizer changes the microbial community structure are complicated (Clegg, 2006) and possibly include several actions. First, mineral nitrogen, as a substrate for growth or respiration, may affect the microbial community structure through the competition of microbes (Clegg, 2006). Second, soil pH, which decreased after ammonium nitrogen fertilization, is an important driver of the microbial community structure (Hansel et al., 2008). Third, CFs significantly increase the soil TN, which can influence the soil C:N ratio, thereby affecting the soil microbial community structure. In addition, $\mathrm{CF}$ influences the soil C:N ratio by stimulating root exudates and increasing the litter-fall quantity through improving the growth of tea plants.

In this study, the bacterial and archaeal abundances were in the same range as those of other studies in acidic soils of other agro-ecosystem (He et al., 2007; Kemnitz et al., 2007). OF amendment increased the bacterial and archaeal abundances (Gattinger et al., 2007; Zhang et al., 2012; Chan et al., 2013), perhaps due to the enhancement of the SOC content. In addition, organic manure may be beneficial to the proliferation of microbes (Sun et al., 2004). However, the CF treatment did not significantly affect the total abundance of bacteria and archaea. Application of $\mathrm{CF}$ not only increases the soil $\mathrm{C}$ content, which increases the total abundance of bacteria and archaea, but also decreases the soil $\mathrm{pH}$, which decreases the total abundances of bacteria and archaea (He et al., 2007).

\subsection{Temporal changes in the abundance of $\mathrm{AOA}$ and $\mathrm{AOB}$ under different fertilizer treatments}

Previously, many studies have reported temporal changes in the abundance of AOA and AOB and attributed these changes to variations in the soil moisture and temperature (Rasche et al., 2011). However, Andert et al. (2011) found that the abundance of AOA did not change over a 9-month experiment. In this study, we found variations in the abundances of $\mathrm{AOA}$ and $\mathrm{AOB}$ with the sampling time that was not correlated with the soil moisture or temperature. Temporal effect is a comprehensive pattern that includes abiotic and biotic factors, such as soil temperature and moisture, rainfall, and tea plant growth. In addition, the soil temperature and moisture affect the plant growth and the transformation of soil nutrients (Gutknecht et al., 2012), and therefore influence the abundances of AOA and AOB indirectly. However, this indirect effect cannot always be detected using a correlation analysis. Interestingly, Rasche et al. (2011) reported that the AOA and AOB abundances were lower in the summer than in the winter, but He et al. (2007) found a contradicted result. The reason for this inconsistency may be differences in the soil types, soil $\mathrm{pH}$, plant types, and other environmental factors.

The abundances of AOA and AOB could be affected by fertilizer amendments. OF, as a source of bioavailable SOC (Ai et al., 2013; Chan et al., 2013), 
stimulated the abundances of $\mathrm{AOA}$ and $\mathrm{AOB}$ ( $\mathrm{He}$ et al., 2007; Shen et al., 2008; Ai et al., 2013). Compared to the $\mathrm{CK}$ treatment, $\mathrm{CF}$ decreased the soil $\mathrm{pH}$ and AOA abundance, as reported by He et al. (2007). However, Ai et al. (2013) found a contradicted result in a calcareous fluvo-aquic soil, possibly because chemical fertilization did not reduce the soil $\mathrm{pH}$ in the calcareous soil as the soil $\mathrm{pH}$ was significantly correlated with the abundance of AOA. CF treatment significantly enhances $\mathrm{AOB}$ abundance in alkaline soils (Shen et al., 2008; Ai et al., 2013) but not in acidic soils (He et al., 2007). In this study, CF increased the AOB abundance due to the increase of SOC, most likely because of the increased litter quantity and the tea root residue. In addition, AOA were more abundant than $\mathrm{AOB}$, indicating that $\mathrm{AOA}$ have a greater role in acidic soils (Yao et al., 2011; Zhang et al., 2011).

\subsection{Temporal changes in the abundance of deni- trifiers under different fertilizer treatments}

Previous studies have demonstrated that the abundance of denitrifying genes fluctuates with the seasons (Dandie et al., 2008; Wakelin et al., 2009; Rasche et al., 2011), but no consistent trend was found (Dandie et al., 2008; Rasche et al., 2011). We found temporal changes in the abundance of denitrifying genes, such as $\operatorname{nar} G, \operatorname{nir} K$, and $\operatorname{nir} S$, which may be due to changes in the soil moisture because the soil moisture was significantly correlated with the abundance of denitrifying genes, with the exception of nos $Z$. The copy numbers of denitrifying genes, such as $n i r K$ and $n i r S$, increase with increasing the water content (Szukics et al., 2010; Di et al., 2014), but nos $Z$ communities exhibit a great stability in response to changes in the soil moisture (Stres et al., 2008). Pastorelli et al. (2011) reported that the season did not affect the nos $Z$-gene-bearing denitrifiers, but we detected a variation of nos $Z$ with the sampling time. Of the measured soil chemical properties, the soil SOC, $\mathrm{pH}$ and $\mathrm{C}: \mathrm{N}$ were significantly correlated with the copy numbers of the nos $Z$ gene. The temporal effect on the copy numbers of the nos $Z$ gene might be due to the combined function of the soil properties and should be studied in future research.

The quantification of the denitrifying genes revealed a lower abundance in tea orchard soil (Hallin et al., 2009; Chen et al., 2012; Clark et al., 2012). The abundances of the denitrifying genes were in the following order: nar $G>\operatorname{nir} K>\operatorname{nir} S>$ nos $Z$. This phenomenon may be caused by the different gene copies within denitrifier genomes (Chen et al., 2012) and the decreased concentration of the denitrifying intermediates in the soil following the reduction order ( $\mathrm{Yu}$ et al., 2008). The greater abundance of nirK than of nirS observed in tea orchard soil was consistent with Clark et al. (2012), but a contrasting phenomenon was reported in grassland (Čuhel et al., 2010). The bacteria carrying nirK genes become more abundant in response to increased $\mathrm{N}$, while the bacteria carrying nirS may have an advantage in low-N soils (Clark et al., 2012). In tea orchards, the soil $\mathrm{N}$ increased due to the input of a large amount of $\mathrm{CF}$ used to enhance the tea yield. The $\mathrm{qPCR}$ analysis revealed that the $\mathrm{OF}$ increased the abundance of denitrifiers due to the added biomass $\mathrm{C}$. Because most denitrifiers are heterotrophs (Saunders et al., 2012), we also found a significant correlation between the SOC as well as the $\mathrm{C}: \mathrm{N}$ and the number of denitrifying genes. However, Hallin et al. (2009) reported that an OF treatment alone did not significantly affect the abundance of denitrifiers. In general, no significant effect of CFs was detected. The CF amendments significantly decreased the soil $\mathrm{pH}$, which was a negative factor regarding the copy numbers of denitrifying genes and could counteract the positive effects of higher SOC induced by CFs (Hallin et al., 2009). In addition, the effect of CFs on denitrifier abundance is likely to be related to the soil C:N ratio, which was reduced by the $\mathrm{N}$ fertilizer amendments, changing the population of denitrifiers (Rösch and Bothe, 2009).

\section{Conclusions}

In conclusion, the results of our field study in the acidic soils of tea orchards indicated that temporal alteration and fertilizer applications significantly influence not only the bacterial and archaeal communities but also the abundances of phylogenetic and functional markers, which can be increased by the use of OF. Future studies should focus on the temporal response of the microbial-driven ecological processes to fertilizer, especially OF, and the relationship between the microbial community and microbial-driven ecological processes in tea crop soil. 


\section{Acknowledgements}

We thank Dr. Lin-fu ZHOU of the School of Medicine, Zhejiang University, China, for his experimental support.

\section{Compliance with ethics guidelines}

Hua WANG, Shao-hui YANG, Jing-ping YANG, Ya-min LV, Xing ZHAO, and Ji-liang PANG declare that they have no conflict of interest.

This article does not contain any studies with human or animal subjects performed by any of the authors.

\section{References}

Ai, C., Liang, G., Sun, J., et al., 2013. Different roles of rhizosphere effect and long-term fertilization in the activity and community structure of ammonia oxidizers in a calcareous fluvo-aquic soil. Soil Biol. Biochem., 57: 30-42. [doi:10.1016/j.soilbio.2012.08.003]

Anderson, M.J., 2001. A new method for non-parametric multivariate analysis of variance. Austral Ecol., 26(1): 32-46. [doi:10.1111/j.1442-9993.2001.01070.pp.x]

Andert, J., Wessén, E., Börjesson, G., et al., 2011. Temporal changes in abundance and composition of ammoniaoxidizing bacterial and archaeal communities in a drained peat soil in relation to $\mathrm{N}_{2} \mathrm{O}$ emissions. J. Soils Sediments, 11(8):1399-1407. [doi:10.1007/s11368-011-0413-9]

Bell, C.W., Acosta-Martinez, V., Mcintyre, N.E., et al., 2009. Linking microbial community structure and function to seasonal differences in soil moisture and temperature in a Chihuahuan desert grassland. Microb. Ecol., 58(4): 827-842. [doi:10.1007/s00248-009-9529-5]

Böhme, L., Langer, U., Böhme, F., 2005. Microbial biomass, enzyme activities and microbial community structure in two European long-term field experiments. Agric. Ecosyst. Environ., 109(1-2):141-152. [doi:10.1016/j.agee. 2005.01.017]

Bomberg, M., Münster, U., Pumpanen, J., et al., 2011. Archaeal communities in boreal forest tree rhizospheres respond to changing soil temperatures. Microb. Ecol., 62(1):205-217. [doi:10.1007/s00248-011-9837-4]

Buckley, D.H., Schmidt, T.M., 2003. Diversity and dynamics of microbial communities in soils from agro-ecosystems. Environ. Microbiol., 5(6):441-452. [doi:10.1046/j.14622920.2003.00404.x]

Calbrix, R., Barray, S., Chabrerie, O., et al., 2007. Impact of organic amendments on the dynamics of soil microbial biomass and bacterial communities in cultivated land. Appl. Soil Ecol., 35(3):511-522. [doi:10.1016/j.apsoil. 2006.10.007]

Chan, Y.K., Mccormick, W.A., Ma, B., 2013. Effects of inorganic fertilizer and manure on soil archaeal abundance at two experimental farms during three consecutive rotation-cropping seasons. Appl. Soil Ecol., 68:26-35. [doi:10.1016/j.apsoil.2013.03.004]

Chen, Z., Liu, J., Wu, M., et al., 2012. Differentiated response of denitrifying communities to fertilization regime in paddy soil. Microb. Ecol., 63(2):446-459. [doi:10.1007/ s00248-011-9909-5]

Clark, I.M., Buchkina, N., Jhurreea, D., et al., 2012. Impacts of nitrogen application rates on the activity and diversity of denitrifying bacteria in the broadbalk wheat experiment. Philos. Trans. R. Soc. B Biol. Sci., 367(1593):1235-1244. [doi:10.1098/rstb.2011.0314]

Clegg, C.D., 2006. Impact of cattle grazing and inorganic fertiliser additions to managed grasslands on the microbial community composition of soils. Appl. Soil Ecol., 31(1-2):73-82. [doi:10.1016/j.apsoil.2005.04.003]

Čuhel, J., Šimek, M., Laughlin, R.J., et al., 2010. Insights into the effect of soil $\mathrm{pH}$ on $\mathrm{N}_{2} \mathrm{O}$ and $\mathrm{N}_{2}$ emissions and denitrifier community size and activity. Appl. Environ. Microbiol., 76(6):1870-1878. [doi:10.1128/AEM.02484-09]

Dandie, C.E., Burton, D.L., Zebarth, B.J., et al., 2008. Changes in bacterial denitrifier community abundance over time in an agricultural field and their relationship with denitrification activity. Appl. Environ. Microbiol., 74(19): 5997-6005. [doi:10.1128/AEM.00441-08]

Di, H.J., Cameron, K.C., Podolyan, A., et al., 2014. Effect of soil moisture status and a nitrification inhibitor, dicyandiamide, on ammonia oxidizer and denitrifier growth and nitrous oxide emissions in a grassland soil. Soil Biol. Biochem., 73:59-68. [doi:10.1016/j.soilbio.2014.02.011]

Enwall, K., Philippot, L., Hallin, S., 2005. Activity and composition of the denitrifying bacterial community respond differently to long-term fertilization. Appl. Environ. Microbiol., 71(12):8335-8343. [doi:10.1128/AEM.71.12. 8335-8343.2005]

Galloway, J.N., Aber, J.D., Erisman, J.W., et al., 2003. The nitrogen cascade. Bioscience., 53(4):341-356. [doi:10. 1641/0006-3568(2003)053[0341:TNC]2.0.CO;2]

Gattinger, A., Höfle, M.G., Schloter, M., et al., 2007. Traditional cattle manure application determines abundance, diversity and activity of methanogenic archaea in arable European soil. Environ. Microbiol., 9(3):612-624. [doi:10. 1111/j.1462-2920.2006.01181.x]

Gray, S.B., Classen, A.T., Kardol, P., et al., 2011. Multiple climate change factors interact to alter soil microbial community structure in an old-field ecosystem. Soil Sci. Soc. Am. J., 75(6):2217-2226. [doi:10.2136/sssaj2011. 0135]

Gutknecht, J.L., Field, C.B., Balser, T.C., 2012. Microbial communities and their responses to simulated global change fluctuate greatly over multiple years. Glob. Change Biol., 18(7):2256-2269. [doi:10.1111/j.13652486.2012.02686.x]

Hallin, S., Jones, C.M., Schloter, M., et al., 2009. Relationship between $\mathrm{N}$-cycling communities and ecosystem functioning in a 50-year-old fertilization experiment. ISME J., 3(5):597-605. [doi:10.1038/ismej.2008.128]

Hansel, C.M., Fendorf, S., Jardine, P.M., et al., 2008. Changes in bacterial and archaeal community structure and functional diversity along a geochemically variable soil profile. Appl. Environ. Microbiol., 74(5):1620-1633. [doi:10.1128/AEM.01787-07] 
Hayden, H.L., Mele, P.M., Bougoure, D.S., et al., 2012. Changes in the microbial community structure of bacteria, archaea and fungi in response to elevated $\mathrm{CO}_{2}$ and warming in an Australian native grassland soil. Environ. Microbiol., 14(12):3081-3096. [doi:10.1111/j.1462-2920. 2012.02855.x]

He, J.Z., Shen, J.P., Zhang, L.M., et al., 2007. Quantitative analyses of the abundance and composition of ammoniaoxidizing bacteria and ammonia-oxidizing archaea of a Chinese upland red soil under long-term fertilization practices. Environ. Microbiol., 9(9):2364-2374. [doi:10. 1111/j.1462-2920.2007.01358.x]

He, J.Z., Zheng, Y., Chen, C.R., et al., 2008. Microbial composition and diversity of an upland red soil under long-term fertilization treatments as revealed by culturedependent and culture-independent approaches. J. Soils Sediments, 8(5):349-358. [doi:10.1007/s11368-0080025-1]

Jung, J., Yeom, J., Han, J., et al., 2012. Seasonal changes in nitrogen-cycle gene abundances and in bacterial communities in acidic forest soils. J. Microbiol., 50(3): 365-373. [doi:10.1007/s12275-012-1465-2]

Kemnitz, D., Kolb, S., Conrad, R., 2007. High abundance of crenarchaeota in a temperate acidic forest soil. FEMS Microbiol. Ecol., 60(3):442-448. [doi:10.1111/j.15746941.2007.00310.x]

Lauber, C.L., Ramirez, K.S., Aanderud, Z., et al., 2013. Temporal variability in soil microbial communities across land-use types. ISME J., 7(8):1641-1650. [doi:10.1038/ ismej.2013.50]

Marschner, P., Kandeler, E., Marschner, B., 2003. Structure and function of the soil microbial community in a longterm fertilizer experiment. Soil Biol. Biochem., 35(3): 453-461. [doi:10.1016/S0038-0717(02)00297-3]

Nelson, D., Sommers, L., 1982. Total carbon, organic carbon and organic matter. In: Page, A., Miller, R., Keeney, D. (Eds.), Methods of Soil Analysis. American Society of Agronomy, Madison, p.539-580.

Nicol, G.W., Glover, L.A., Prosser, J.I., 2003. The impact of grassland management on archaeal community structure in upland pasture rhizosphere soil. Environ. Microbiol., 5(3):152-162. [doi:10.1046/j.1462-2920.2003.00399.x]

Norman, R.J., Edberg, J.C., Stucki, J.W., 1985. Determination of nitrate in soil extracts by dual-wavelength ultraviolet spectrophotometry. Soil Sci. Soc. Am. J., 49(5):11821185. [doi:10.2136/sssaj1985.03615995004900050022x]

Ogilvie, L.A., Hirsch, P.R., Johnston, A.W., 2008. Bacterial diversity of the broadbalk 'classical' winter wheat experiment in relation to long-term fertilizer inputs. Microb. Ecol., 56(3):525-537. [doi:10.1007/s00248-008-9372-0]

Pandey, A., Palni, L.M.S., 1996. The rhizosphere effect of tea on soil microbes in a himalayan monsoonal location. Biol. Fertil. Soils., 21(3):131-137. [doi:10.1007/BF00335924]

Pastorelli, R., Landi, S., Trabelsi, D., et al., 2011. Effects of soil management on structure and activity of denitrifying bacterial communities. Appl. Soil Ecol., 49:46-58. [doi:10. 1016/j.apsoil.2011.07.002]

Peacock, A.G., Mullen, M., Ringelberg, D., et al., 2001. Soil microbial community responses to dairy manure or ammonium nitrate applications. Soil Biol. Biochem., 33(7-8): 1011-1019. [doi:10.1016/S0038-0717(01)00004-9]

Prosser, J.I., Nicol, G.W., 2012. Archaeal and bacterial ammonia-oxidisers in soil: the quest for niche specialisation and differentiation. Trends Microbiol., 20(11): 523-531. [doi:10.1016/j.tim.2012.08.001]

Rasche, F., Knapp, D., Kaiser, C., et al., 2011. Seasonality and resource availability control bacterial and archaeal communities in soils of a temperate beech forest. ISME J., 5(3):389-402. [doi:10.1038/ismej.2010.138]

Rösch, C., Bothe, H., 2009. Diversity of total, nitrogen-fixing and denitrifying bacteria in an acid forest soil. Eur. J. Soil Sci., 60(6):883-894. [doi:10.1111/j.1365-2389.2009. 01167.x]

Saunders, O.E., Fortuna, A.M., Harrison, J.H., et al., 2012. Gaseous nitrogen and bacterial responses to raw and digested dairy manure applications in incubated soil. Environ. Sci. Technol., 46(21):11684-11692. [doi:10. 1021/es301754s]

Shen, J.P., Zhang, L.M., Zhu, Y.G., et al., 2008. Abundance and composition of ammonia-oxidizing bacteria and ammonia-oxidizing archaea communities of an alkaline sandy loam. Environ. Microbiol., 10(6):1601-1611. [doi: 10.1111/j.1462-2920.2008.01578.x]

Stark, C.H., Condron, L.M., O'Callaghan, M., et al., 2008. Differences in soil enzyme activities, microbial community structure and short-term nitrogen mineralisation resulting from farm management history and organic matter amendments. Soil Biol. Biochem., 40(6):13521363. [doi:10.1016/j.soilbio.2007.09.025]

Stres, B., Danevčič, T., Pal, L., et al., 2008. Influence of temperature and soil water content on bacterial, archaeal and denitrifying microbial communities in drained fen grassland soil microcosms. FEMS Microbiol. Ecol., 66(1): 110-122. [doi:10.1111/j.1574-6941.2008.00555.x]

Sun, B., 2007. Protocols for Standard Soil Observation and Measurement in Terrestrial Ecosystems. China Environmental Science Press, Beijing, China, p.165-166 (in Chinese).

Sun, H., Deng, S., Raun, W., 2004. Bacterial community structure and diversity in a century-old manure-treated agroecosystem. Appl. Environ. Microbiol., 70(10):58685874. [doi:10.1128/AEM.70.10.5868-5874.2004]

Szukics, U., Abell, G.C., Hödl, V., et al., 2010. Nitrifiers and denitrifiers respond rapidly to changed moisture and increasing temperature in a pristine forest soil. FEMS Microbiol. Ecol., 72(3):395-406. [doi:10.1111/j.15746941.2010.00853.x]

Wakelin, S.A., Gregg, A.L., Simpson, R.J., et al., 2009. Pasture management clearly affects soil microbial community structure and N-cycling bacteria. Pedobiologia, 52(4):237-251. [doi:10.1016/j.pedobi.2008.10.001]

Wang, Y., Zhu, G., Song, L., et al., 2014. Manure fertilization 
alters the population of ammonia-oxidizing bacteria rather than ammonia-oxidizing archaea in a paddy soil. $J$. Basic Microbiol., 54(3):190-197. [doi:10.1002/jobm. 201200671]

Wessén, E., Nyberg, K., Jansson, J.K., et al., 2010. Responses of bacterial and archaeal ammonia oxidizers to soil organic and fertilizer amendments under long-term management. Appl. Soil Ecol., 45(3):193-200. [doi:10.1016/j. apsoil.2010.04.003]

Wolsing, M., Priemé, A., 2004. Observation of high seasonal variation in community structure of denitrifying bacteria in arable soil receiving artificial fertilizer and cattle manure by determining T-RFLP of nir gene fragments. FEMS Microbiol. Ecol., 48(2):261-271. [doi:10.1016/ j.femsec.2004.02.002]

Yao, H., Gao, Y., Nicol, G.W., et al., 2011. Links between ammonia oxidizer community structure, abundance, and nitrification potential in acidic soils. Appl. Environ. Microbiol., 77(13):4618-4625. [doi:10.1128/AEM.00136-11]

Yu, K., Struwe, S., Kjøller, A., et al., 2008. Denitrification rate determined by nitrate disappearance is higher than determined by nitrous oxide production with acetylene blockage. Ecol. Eng., 32(1):90-96. [doi:10.1016/j.ecoleng. 2007.09.006]
Zhang, L.M., Hu, H.W., Shen, J.P., et al., 2011. Ammoniaoxidizing archaea have more important role than ammoniaoxidizing bacteria in ammonia oxidation of strongly acidic soils. ISME J., 6(5):1032-1045. [doi:10.1038/ismej. 2011.168]

Zhang, Q.C., Shamsi, I.H., Xu, D.T., et al., 2012. Chemical fertilizer and organic manure inputs in soil exhibit a vice versa pattern of microbial community structure. Appl. Soil Ecol., 57:1-8. [doi:10.1016/j.apsoil.2012.02.012]

Zumft, W.G., 1997. Cell biology and molecular basis of denitrification. Microbiol. Mol. Biol. Rev., 61(4): 533-616.

\section{List of electronic supplemental materials}

Fig. S1 Plots of nonmetric multidimensional scaling of microbial communities based T-RFLP data sets obtained from total bacteria (a) and total archaea (b) among organic fertilizer (OF), chemical fertilizer (CF), and unfertilized control (CK) treatments

Table S1 Description of primers, amplification details used for quantitative PCR and T-RFLP analysis

Table S2 Soil properties determined over a year period with organic fertilizer (OF), chemical fertilizer (CF), and unfertilized control (CK) treatments

\section{中文概要:}

\section{本文题目：不同肥料处理下茶园土壤细菌和古菌群落的时间变化研究}

Temporal changes in soil bacterial and archaeal communities with different fertilizers in tea orchards

研究目的: 研究化学肥料和有机肥处理条件下, 茶园酸性土壤细菌和古菌群落结构, 以及氮素转化相 关功能酶基因丰度的时间变化规律。

创新要点: 研究肥料、土壤温度及土壤含水量对茶园酸性土壤细菌和古菌群落结构, 以及氮素转化相 关功能酶基因丰度的影响。

研究方法: 应用末端限制性片段长度多态性 (T-RFLP) 技术分析茶园酸性土壤中细菌和古菌群落结构 随时间的变化规律，应用苂光定量聚合酶链式反应（PCR）技术，研究茶园酸性土壤细菌、 古菌、硝化作用功能酶基因 (细菌和古菌 $a m o A$ 基因) 和细菌反硝化作用功能酶基因 (narG、 $n i r K$ 、nirs 和 $n o s Z$ 基因）丰度的时间变化规律。

重要结论: 茶园土壤细菌和古菌群落结构受到肥料的影响, 并随着取样时间有显著的变化。细菌、古 菌和古菌的 $a m o A$ 基因的丰度在 7 月份最小，而细菌的 $a m o A$ 基因和反硝化作用功能酶基因 （除 nirK 基因）的丰度在 9 月份最小。有机肥处理增加了细菌、古菌和氮素转化相关功能 酶基因的丰度, 但化学肥料的施用对菌群及功能酶基因丰度的影响较小。土壤温度显著影 响了土壤细菌和古菌的群落结构。土壤含水量与细菌反硝化作用功能酶基因有显著的相关 性。土壤有机碳含量与细菌、古菌及功能酶基因丰度之间有显著的相关性。

关键词组: 茶园; 时间变化; 肥料; 细菌和古菌群落; 氮素转化相关功能酶基因 